\title{
Growth and meat quality of broiler chickens fed Moringa oleifera leaf meal, a probiotic and an organic acid
}

\author{
X.P. Nduku1, ${ }^{2 \#}$, S.P. Mabusela ${ }^{3} \&$ T.T. Nkukwana ${ }^{3}$ \\ ${ }^{1}$ Agricultural Research Council, Private Bag X2, Irene 0062, South Africa \\ ${ }^{2}$ Department of Livestock and Pasture Science, University of Fort Hare, Private Bag X1314, Alice 5700, South Africa \\ ${ }^{3}$ Department of Wildlife and Animal Science, University of Pretoria, Private Bag X20, Pretoria 0028, South Africa
}

(Submitted 25 March 2019; Accepted 10 July 2020; Published 5 November 2020)

\begin{abstract}
Copyright resides with the authors in terms of the Creative Commons Attribution 4.0 South African Licence.
See: http://creativecommons.org/licenses/by/4.0/za

Condition of use: The user may copy, distribute, transmit and adapt the work, but must recognise the authors and the South African Journal of Animal Science.
\end{abstract}

\begin{abstract}
Six hundred one-day-old broiler chicks were used to determine the effects of Moringa oleifera leaf meal (MOLM), a probiotic, and an organic acid on growth, weights of digestive organs, and meat quality. Starter, grower, and finisher diets were formulated to which the additives were supplemented, namely T1: $300 \mathrm{~g} /$ ton zinc bacitracin and $500 \mathrm{~g} /$ ton salinomycin; T2: $1000 \mathrm{~g} /$ ton MOLM; T3: probiotic (500 g/ton Enviva Pro); T4: organic acid (1000 g/ton Novyrate C); and T5: without additives. Bodyweight (BW), average daily gain (ADG), and feed intake (FI) were measured weekly through day 28 . On days 1 to 7 , FI was highest for T4 $(22.01 \mathrm{~g} / \mathrm{d})$ and lowest for T2 $(20.13 \mathrm{~g} / \mathrm{d})$. Birds in T3 had the lowest ADG and highest FCR on days 21 to 28 , and the highest BW on day 14 and day 21 . Twelve birds were randomly selected from each treatment to measure carcass yield, organ sizes and meat quality. $\mathrm{pH}$ of the breast muscle was recorded at 45 minutes and 24 hours post mortem. Colour and drip loss were measured 24 hours post mortem. Birds in T4 had the lightest carcasses (1451 g). Birds in T2 had higher redness and chroma values, while hue angle values were highest in T3 birds. The effects of MOLM were comparable with the probiotic and organic acid. That is, they improved growth performance, digestive organ size and meat quality characteristics when included in broiler diets as alternatives to antibiotic growth promoters (AGP).
\end{abstract}

Keywords: alternative growth promoters, carcass characteristics, digestive organ size, feed conversion "Corresponding author: xpnduku@gmail.com

\section{Introduction}

Poultry nutrition research is focusing on functional nutritional mechanisms to formulate high-quality feeds that would improve the efficiency of feed utilization and growth performance, and produce the desired carcass and meat quality attributes (Kidd, 2009). For a long time, antibiotics were used to maximize the utilization of nutrients in feed and enhance growth performance and production of poultry (Huyghebaert et al., 2011; Phillips et al., 2004). But consumers are rejecting the use of antibiotics in animal feeds because of their association with human and animal health risks (Gonzalez \& Angeles, 2017). Although the inclusion of alternative growth promoters (AGP) in animal feed was banned in the European Union countries in 2006, it is widely practised in the South African poultry industry, where the effects of AGP are alleviated by feeding an AGP-free 'withdrawal' diet before slaughter. Various alternatives to AGP, such as probiotics and organic acids, are currently being used commercially to enhance health status, feed quality and utilization, and production efficiency in poultry (Khan \& Naz, 2013; Khan et al., 2016; Abudabos et al., 2016; Abudabos et al., 2017). Included in these potential AGP replacements are phytogenic feed additives that are extracted from medicinal plants. Eleroğlu et al. (2013) recommended incorporating natural plant extracts in animal diets as this improved the oxidative stability, shelf-life and colour of meat, because of the presence of flavonoids and other phenolic compounds that have anti-oxidative and hypocholesterolemic effects on poultry products.

Moringa oleifera Lam. (Moringa) is a highly valued nutritious plant that is distributed throughout various climatic zones and countries (Anwar et al., 2007). Moringa leaves could be used as an alternative to AGP, as they contain an impressive range of nutritional, growth promoting, prophylactic, antimicrobial and antioxidant properties (Moyo et al., 2012;). The leaf extracts of Moringa exhibit antioxidant activity owing to 
the abundance of phenolic acids and flavonoids (Al Khateeb et al., 2013). The dietary inclusion of graded levels of MOLM as an alternative to protein has been evaluated (Zanu et al., 2012). However, there is a dearth of conclusive work on the effects of MOLM that are comparable with commercial AGP and other feed additives in broiler diets. The objective of the study was thus to compare the effects of MOLM with a probiotic and an organic acid in improving growth performance, digestive organ size and meat quality characteristics when included in broiler diets as alternatives to AGP.

\section{Materials and methods}

Ethical principles in this study conformed to national and international standards governing research of this nature with the usage of broiler chickens. Permission to use the experimental birds was obtained from the Ethical Committee of the University of Fort Hare (MUC221SNDU01) and from the ARC-AP (APAEC [2019/13]). The management of the birds was in accordance with the principles of animal care in experimentation (SANS, 2008). The feeding programme consisted of a starter (0 to 21 days) and a grower (22 to 28 days) basal diet formulated on Win-Feed 3.0 formulation software to meet the birds' dietary nutrient requirements (NRC, 1994). Each feed consisted of the basal diet with or without additives and was split into five treatment groups, namely T1: positive control, $300 \mathrm{~g} / \mathrm{ton}$ zinc bacitracin, and $500 \mathrm{~g} / \mathrm{ton}$ salinomycin; T2: $1000 \mathrm{~g} /$ ton Moringa oleifera leaf meal; T3: $500 \mathrm{~g} / \mathrm{to}$ probiotic (Enviva® Pro); T4: $1000 \mathrm{~g} /$ ton organic acid (Novyrate ${ }^{\circledR}$ C); and T5: negative control, $0 \%$ additives). The composition of the maize-soybean basal starter, grower, and finisher diets on as-fed basis is shown in Table 1. The physical form of the starter was crumbs and the grower and finisher diets were pellets.

Table 1 Composition of basal starter, grower, and finisher diets for broiler chickens on as-fed basis

\begin{tabular}{lrc}
\hline & \multicolumn{2}{c}{ Diets per feeding phase } \\
\cline { 2 - 3 } Feed ingredient $(\mathrm{g} / \mathrm{kg})$ & Starter $(1-21$ days $)$ & Grower $(22$ - 28 days $)$ \\
\hline & & 544.4 \\
Maize & 626.6 & 210 \\
Soybean $44 \%$ crude protein & 200 & 50 \\
Soybean full fat & 18.3 & 47.46 \\
Fish meal 65 & 120 & 50.04 \\
Sunflower 37 & 0 & 50 \\
Oil flower & 0 & 13.46 \\
Choline chloride 60\% & 8.98 & 10.84 \\
Limestone & 7.6 & 11.38 \\
Kynofos & 5.56 & 5.73 \\
Sodium bicarbonate & 3.54 & 2.62 \\
Lysine HCL & 2.24 & 1.5 \\
Vitamin + mineral premix* & 1.5 & 1.11 \\
L-threonine & 1.13 & 1.45 \\
DL methionine & 1.07 & 0 \\
Tryphtophan & 0.15 & \\
\end{tabular}

${ }^{*}$ Per $\mathrm{kg}$ of feed, vitamin $\mathrm{A}: 11000 \mathrm{IU}$, vitamin $\mathrm{D}_{3}: 5000 \mathrm{IU}$, vitamin $\mathrm{E}: 60 \mathrm{mg}$, vitamin $\mathrm{K}_{3}: 2 \mathrm{mg}$, vitamin $\mathrm{B}_{1}: 2 \mathrm{mg}$, vitamin $B_{2}: 5 \mathrm{mg}$, vitamin $B_{3}: 50 \mathrm{mg}$, vitamin $B_{5}: 2 \mathrm{mg}$, vitamin $B_{6}: 3 \mathrm{mg}$, vitamin $B_{9}: 2 \mathrm{mg}$, vitamin $B_{12}: 0.01 \mathrm{mg}$, biotin: $0.1 \mathrm{mg}$, antioxidant: $125 \mathrm{mg}$, manganese: $110 \mathrm{mg}$, iron: $40 \mathrm{mg}$, zinc: $100 \mathrm{mg}$, copper: $10 \mathrm{mg}$, cobalt: $0.5 \mathrm{mg}$, iodine: $2 \mathrm{mg}$, selenium: $0.3 \mathrm{mg}$, choline: $350 \mathrm{mg}$

Proximate analyses for moisture, crude protein, ash and ether extract were performed on all experimental diets and on MOLM according to the methods of the Association of Official Analytical Chemists (AOAC, 2000) to confirm the composition and quality of nutrients (Table 2). A total of 600 one-day-old unsexed Cobb 500 broiler chicks were randomly allocated to 30 floor pens containing fresh wood shavings to the depth of $5 \mathrm{~cm}$ in an environmentally controlled house, and were reared for 28 days maximum. The experiment was a completely randomized design divided into 5 dietary treatments with 6 replicate groups of 
20 birds per pen. House temperature was set and maintained at $34{ }^{\circ} \mathrm{C}$ during the first week and then reduced by $3^{\circ} \mathrm{C}$ per week until $22{ }^{\circ} \mathrm{C}$ was reached and maintained at this level until the end of the experiment. Chicks were inspected daily and dead birds were removed after mortality was recorded (pen, date, and bodyweight), and feed consumption data were corrected for bodyweight of mortality. Feed and fresh water were offered throughout the production cycle.

Table 2 Analysed nutrient composition of experimental diets for broiler chickens and Moringa oleifera leaf meal on dry matter basis

\begin{tabular}{cccccccccccc}
\hline Diet & $\begin{array}{c}\text { DM, } \\
\%\end{array}$ & $\begin{array}{c}\text { Moisture, } \\
\%\end{array}$ & $\begin{array}{c}\text { Ash, } \\
\%\end{array}$ & $\begin{array}{c}\text { EE, } \\
\%\end{array}$ & $\begin{array}{c}\text { CF, } \\
\%\end{array}$ & $\begin{array}{c}\text { CP, } \\
\%\end{array}$ & $\begin{array}{c}\text { NFE, } \\
\%\end{array}$ & $\begin{array}{c}\text { ADF, } \\
\%\end{array}$ & $\begin{array}{c}\text { NDF, } \\
\%\end{array}$ & $\begin{array}{c}\text { Ca, } \\
\%\end{array}$ & $\begin{array}{c}\text { P, } \\
\%\end{array}$ \\
\hline Starter & & & & & & & & & & & \\
T1 & 89.33 & 10.67 & 6.02 & 5.03 & 3.31 & 22.01 & 52.96 & 4.85 & 18.49 & 1.19 & 0.69 \\
T2 & 89.23 & 10.77 & 5.69 & 4.73 & 3.28 & 21.86 & 53.67 & 3.91 & 19.62 & 1.22 & 0.67 \\
T3 & 87.97 & 12.03 & 4.17 & 4.28 & 3.54 & 21.14 & 54.84 & 4.44 & 18.56 & 0.70 & 0.52 \\
T4 & 88.70 & 11.30 & 5.35 & 5.25 & 3.86 & 22.83 & 51.41 & 5.04 & 16.58 & 0.96 & 0.66 \\
T5 & 88.47 & 11.53 & 4.91 & 4.97 & 3.19 & 21.63 & 53.77 & 3.78 & 17.17 & 1.01 & 0.59 \\
Grower & & & & & & & & & & & \\
T1 & 90.20 & 9.80 & 5.47 & 9.89 & 4.98 & 21.67 & 48.19 & 6.22 & 11.44 & 0.93 & 0.76 \\
T2 & 89.84 & 10.16 & 5.21 & 9.73 & 4.59 & 19.87 & 50.44 & 7.02 & 11.37 & 1.00 & 0.75 \\
T3 & 90.59 & 9.41 & 5.23 & 10.20 & 4.93 & 21.09 & 49.14 & 5.17 & 12.11 & 0.96 & 0.63 \\
T4 & 90.32 & 9.68 & 4.82 & 10.16 & 4.43 & 20.78 & 50.13 & 6.68 & 11.45 & 0.92 & 0.63 \\
T5 & 90.42 & 9.58 & 4.83 & 10.47 & 4.69 & 20.44 & 49.99 & 8.53 & 10.86 & 0.98 & 0.61 \\
Finisher & & & & & & & & & & & \\
T1 & 88.51 & 10.74 & 4.45 & 9.20 & 3.8 & 18.93 & 52.13 & 4.57 & 14.43 & 0.72 & 0.55 \\
T2 & 87.17 & 12.83 & 4.34 & 8.80 & 4.12 & 19.12 & 50.71 & 5.10 & 13.72 & 0.79 & 0.54 \\
T3 & 87.72 & 12.28 & 4.57 & 8.10 & 4.00 & 17.76 & 53.90 & 4.54 & 13.67 & 0.75 & 0.55 \\
T4 & 88.17 & 11.83 & 4.53 & 7.96 & 3.76 & 18.21 & 53.71 & 5.14 & 14.35 & 0.82 & 0.55 \\
T5 & 87.17 & 12.83 & 4.38 & 7.93 & 4.03 & 22.73 & 48.10 & 5.71 & 13.31 & 0.81 & 0.56 \\
MOLM & 92.70 & 7.30 & 8.73 & 5.08 & 5.86 & 24.96 & 48.07 & 5.82 & 10.12 & 1.77 & 0.28
\end{tabular}

DM: dry matter, EE: ether extract, CF: crude fibre, CP: crude protein, NFE: nitrogen-free extract, ADF: acid detergent fibre, NDF: neutral detergent fibre, Ca: calcium, P: phosphorus, T1: positive control with $300 \mathrm{~g} /$ ton zinc bacitracin and $500 \mathrm{~g} /$ ton salinomycin, T2: $1000 \mathrm{~g} /$ ton Moringa oleifera leaf meal (MOLM), T3: $500 \mathrm{~g} /$ ton probiotic, T4: $1000 \mathrm{~g} /$ ton organic acid, T5: negative control, without additives

Feed allocated and the weight of birds per pen were recorded at placement, and then at weekly intervals, that is, 7, 14, 21 and 28 days old. Bodyweight gain (BWG, g) was calculated as final bodyweight minus initial bodyweight, and average daily gains (ADG) were calculated as weekly averages. Feed conversion ratio (FCR) was calculated as FI divided by BWG, on a pen weight basis. After 28 days, all the birds were slaughtered, and twelve birds were randomly selected from each treatment (two per replicate), making 60 birds. Birds were weighed individually before they were slaughtered by cervical dislocation following electrical stunning at a voltage of 70 volts. The carcasses were then eviscerated manually. The gizzards and the visceral organs (liver, lung, heart and spleen) were removed by hand through incisions around the vent and sternum. Gizzards were collected to determine the levels of erosion by visual observation using four grading codes from 0 to $3(0=$ normal gizzard; 1 = slight erosion; $2=$ definite erosion, $3=$ severe erosion). Carcasses and visceral organs were then weighed individually (per bird), and expressed as percentages of live bodyweight. Dressing percentage was calculated as carcass weight divided by preslaughter bodyweight.

Carcass weight and breast $\mathrm{pH}$ were recorded 45 minutes post mortem $\left(\mathrm{pH}_{45}\right)$. The carcases were then kept in refrigerated storage at $4{ }^{\circ} \mathrm{C}$. At 24 hours post mortem, the chilled carcass weights and breast $\mathrm{pH}$ $\left(\mathrm{pH}_{24}\right)$ were measured. The $\mathrm{pH}$ was determined with a portable digital $\mathrm{pH}$ meter equipped with a probe and 
an X5 sensor electrode (Eutech Instruments Pte Ltd., Singapore). Breast meat colour coordinates were measured with a Konica Minolta CM-600d colour meter using colour data software CM-S 100W SpectaMagic NX (Konica Minolta, Hanover, Germany). The colour measurements were made approximately 24 hours after slaughter and one hour after blooming (CIE-Lab, 1978). The calorimeter was calibrated with the green standard before measurements were taken. Three readings were taken on non-overlapping zones of the sample rotated $10^{\circ}$ between measurements and the average values were obtained. The chroma $\left(\mathrm{C}^{*}\right)$ and hue angle $\left(\mathrm{H}^{*}\right)$ were calculated with the formulae $\mathrm{C}^{*}=\left[\left(\mathrm{a}^{*} 2+\mathrm{b}^{*} 2\right) 0.5\right]$ and $\mathrm{H}^{*}=\left[\left(\tan -1\left(\mathrm{~b}^{*} / \mathrm{a}^{*}\right)\right]\right.$.

Breast muscle samples were weighed (W1) and placed individually in a cooler $\left(4^{\circ} \mathrm{C}\right)$ for drip loss percentage analysis. After 12 hours the samples were removed from the cooler and were wiped with absorbent paper, and dry breast muscle weight was measured (W2). Drip loss percentage was calculated as $[(\mathrm{W} 1-\mathrm{W} 2) \div \mathrm{W} 1 \times 100]$. Water-holding capacity $(\mathrm{WHC})$ was determined by calculating the ratio of meat area to liquid area after pressing a 400 to $600 \mathrm{mg}$ meat sample on a filter paper (Whatman 4) sandwiched between two Perspex plates, and pressed at constant pressure for 5 min (Grau \& Hamm, 1953). Following Irie et al. (1996), areas were measured with a VIA system composed of an Olympus CC12 camera and CellSens imaging software (version 1.14; Olympus Corp., Shinjuku, Japan). Water-holding capacity was expressed as the area of the meat divided by the area of the moisture.

For growth performance, digestive organ weight, carcass yield and meat quality parameter data, an analysis of variance was computed using the generalized linear model (GLM) procedure of SAS/STAT® software 9.4 (SAS Institute Inc., Cary, North Carolina, USA). The model was:

$$
Y_{i j}=\mu+a_{i}+e_{i j}
$$

Where: $Y_{i j}=$ response variable,

$\mu=$ the common mean,

$\alpha_{i}=$ the effect of the ith dietary treatment $(T 1, T 2, T 3, T 4$ and T5), and

$e_{i j}=$ the random error.

Data were presented as the least square means with their standard error. The least significant difference (LSD) method was used to test differences between means for significance. Differences were considered significant at $P<0.05$.

\section{Results and Discussion}

Differences in BW were observed only at 14 days and 21 days old. At 14 days, the birds in T2 had lower $(P<0.05)$ BW $(505 \mathrm{~g})$ than those in T3 $(528.33 \mathrm{~g})$, but were similar $(P>0.05)$ to the birds from other groups. At 21 days, T2 and T4 birds had lower $(P<0.05)$ BW than birds in T3, but were not different $(P$ $>0.05$ ) from each other and the birds in other groups. This suggests that MOLM affects BW in the same way as an AGP and an organic acid. The higher BW of the birds fed T3 was probably because of the beneficial effect of probiotics on the gut flora (Ashayerizadeh et al., 2009). Through the process of competitive exclusion, T3 ensures that there is limited space for inflammation and necrosis-causing bacteria that may cost energy during immune response and cell repair. Differences in AFI were only noted in the first week (days 1 to 7), where birds in T2 (fed MOLM) had a lower $(P<0.05)$ AFI $(20.13 \mathrm{~g})$ than birds in T4 $(22.01 \mathrm{~g})$. However, T2 and T4 birds had similar $(P>0.05)$ average feed intake (AFI) to the birds in other treatment groups. The effects of dietary treatments on BW, AFI, ADG and FCR for 28 days are shown in Table 3. Lower feed intake in MOLM-fed birds may possibly be because of anti-nutritional factors in Moringa leaves that inhibit the bioavailability of the nutrients (Alidou et al., 2016), and affect production parameters negatively, including bodyweight. Similar to the current findings on AFI, Juniar et al. (2008) reported that the inclusion of MOLM at amounts up to $10 \%$ did not affect $(P>0.05)$ feed consumption, BW and FCR.

Differences in ADG were evident only from 21 to 28 days, when T2 birds had higher $(P<0.05)$ ADG than T3, although not different from birds in other groups. This higher value was reflected in the AFI of MOLM-fed birds, although not significant. Higher ADG in MOLM-fed birds may be caused by the FI regulating effect exerted by Moringa leaves that improves ADG in broiler chickens. Moringa leaves contain phenolics that cause increased glycolysis and utilization of glucose for energy production (Mbikay, 2012). In the second week (8 to 14 days), T3 birds had lower $(P<0.05)$ FCR than birds in T1, although not different $(P$ $>0.05$ ) from that of T2, T4, and T5 birds. This indicates that probiotic diets could affect the growth performance of birds positively (Kocher et al., 2004). The FCR of T2 birds did not differ from that of birds fed AGP, probiotic and organic acids. This finding revealed that a growth promoter effect was exerted by MOLM, similar to the other feed additives, including AGP. The main site of activity in plant extracts such as MOLM is in the gastro-intestinal tract through modification of gut micro-flora, maximizing feed digestibility and growth rate (Nkukwana, 2012). Kwedibana (2008) evaluated the effects of MOLM on the growth rate of broilers and 
found that MOLM in broiler diets promoted significantly higher FCR. Gunal et al. (2006) and Agboola et al. (2015) reported that supplementation of probiotics, organic acid and AGP to broiler diets did not have any effect on growth performance parameters. However, few studies reported the comparative effects of MOLM with other feed additives.

Table 3 Least square means ( \pm standard errors) of growth parameters of broilers fed diets with Moringa oleifera leaf meal, probiotic or organic acid as feed additives for broilers

\begin{tabular}{lrrrrrr}
\hline & \multicolumn{5}{c}{ Dietary treatments } \\
\cline { 2 - 7 } & \multicolumn{7}{c}{ T1 } & \multicolumn{2}{c}{ T3 } & T4 & T5 \\
\hline Bodyweight, g & & & & & \\
Day 1 & 52.33 & 52.33 & 52.33 & 52.33 & 52.33 & 0.33 \\
Day 7 & 184.83 & 180.17 & 184.83 & 186.17 & 183.00 & 3.45 \\
Day 14 & $508.33^{\mathrm{ab}}$ & $505.00^{\mathrm{b}}$ & $528.33^{\mathrm{a}}$ & $511.67^{\mathrm{ab}}$ & $515.00^{\mathrm{ab}}$ & 7.90 \\
Day 21 & $996.97^{\mathrm{ab}}$ & $965.00^{\mathrm{b}}$ & $1028.33^{\mathrm{a}}$ & $985.00^{\mathrm{b}}$ & $988.33^{\mathrm{ab}}$ & 15.71 \\
Day 28 & 1667.67 & 1641.83 & 1622.33 & 1648.17 & 1656.00 & 33.05 \\
Average feed intake, g/d & & & & & \\
Days 1-7 & $21.14^{\mathrm{ab}}$ & $20.13^{\mathrm{b}}$ & $20.89^{\mathrm{ab}}$ & $22.01^{\mathrm{a}}$ & $21.32^{\mathrm{ab}}$ & 0.57 \\
Days 8-14 & 55.69 & 54.75 & 52.67 & 54.26 & 55.45 & 2.32 \\
Days 15-21 & 94.28 & 88.45 & 93.09 & 92.34 & 116.66 & 10.87 \\
Days 21-28 & 131.58 & 129.92 & 126.88 & 126.42 & 132.49 & 3.17 \\
Average daily gain, g/d & & & & & & \\
Days 1-7 & 18.93 & 18.26 & 18.93 & 19.12 & 18.67 & 0.52 \\
Days 8-14 & 46.21 & 46.40 & 49.07 & 46.49 & 47.43 & 1.02 \\
Days 15-21 & 69.76 & 65.71 & 71.43 & 67.62 & 67.62 & 2.19 \\
Days 21-28 & $95.86^{\mathrm{a}}$ & $96.69^{\mathrm{a}}$ & $84.85^{\mathrm{b}}$ & $94.74^{\mathrm{a}}$ & $95.38^{\mathrm{a}}$ & 3.45 \\
Feed conversion ratio & & & & & & \\
Days 1-7 & 1.12 & 1.10 & 1.11 & 1.15 & 1.15 & 0.04 \\
Days 8-14 & $1.20^{\mathrm{a}}$ & $1.18^{\mathrm{ab}}$ & $1.07^{\mathrm{b}}$ & $1.17^{\mathrm{ab}}$ & $1.17^{\mathrm{ab}}$ & 0.05 \\
Days 15-21 & 1.35 & 1.36 & 1.31 & 1.37 & 1.75 & 0.17 \\
Days 21-28 & $1.38^{\mathrm{b}}$ & $1.36^{\mathrm{b}}$ & $1.49^{\mathrm{a}}$ & $1.34^{\mathrm{b}}$ & $1.39^{\mathrm{b}}$ & 0.04 \\
\hline
\end{tabular}

${ }^{a, b}$ Within a row, means with common superscript were not different with probability $P<0.05$

T1: positive control with $300 \mathrm{~g} /$ ton zinc bacitracin and $500 \mathrm{~g} / \mathrm{ton}$ salinomycin, T2: $1000 \mathrm{~g} / \mathrm{ton}$ Moringa oleifera leaf meal (MOLM), T3: $500 \mathrm{~g} /$ ton probiotic, T4: $1000 \mathrm{~g} /$ ton organic acid, T5: negative control, without additives

Differences were observed in carcass weights, in which the birds in T4 showed lower $(P<0.05)$ $(1451.67 \mathrm{~g})$ weights than birds in T1 $(1610.00 \mathrm{~g})$. There were no differences in chilled carcass weights, dressing percentage and digestive organ size among the treatments. The detected lack of a growthpromoting effect may be related to the digestible diets in this study. In general, the beneficial effects of most additives are clearer in suboptimal and stressful conditions (Baurhoo et al., 2007). The results of the current study are compatible with the results drawn from the study by Corduk et al. (2008), in which a probiotic, prebiotic, plant extract and organic acid in broiler diets did not affect carcass and digestive organ parameters significantly. Agboola et al. (2015) reported a lack of additive effect on the digestive organs in a study in which probiotic and organic acid diets had no effects on lung, heart, spleen, liver, and kidneys. Nkukwana et al. (2014) reported no differences in chilled carcass weights, dressed carcass and digestive organs (liver, heart, spleen and gizzard) of broilers fed MOLM from those of the control.

In the current study, the gizzard weight was higher $(P<0.05)$ in T2, T3, T4 and T5 birds than in the positive control group, with birds in T2 having a generally larger gizzard size $(35.83 \mathrm{~g})$, which is indicative of better muscle development, which may have a positive effect on the particle size of digesta and nutrient 
absorption (Kokoszyński et al., 2017). However, Nkukwana et al. (2014) found neither antibiotics nor MOLM had a significant effect on gizzard size. Gizzard development is positively affected by consuming coarse materials which ensures complete grinding of the feed and a well-regulated digesta flow and secretion of digestive juices (Sacranie et al., 2012).

Spleen size was smaller $(P<0.05)$ in T4 birds, and larger in T2 and T5 birds. The smaller spleen in T4 birds may be linked to their lowest carcass weights, compared with birds in other groups. Similarly, Fascina et al. (2017) reported that chickens fed diets containing phytogenic additives and organic acid showed higher relative weight of spleen than those that were not fed with these additives $(P<0.05)$. Table 4 shows the effects of dietary treatments on carcass yield, organ size, and gizzard erosion score.

Table 4 Least square means ( \pm standard errors) of carcass yield, organ size and gizzard erosion score of broilers fed diets with Moringa oleifera leaf meal, probiotics or organic acid as feed additives

\begin{tabular}{lrrrrrr}
\hline \multirow{2}{*}{ Traits } & \multicolumn{7}{c}{ Dietary treatments } \\
\cline { 2 - 7 } & \multicolumn{1}{c}{ T1 } & \multicolumn{1}{c}{ T3 } & \multicolumn{1}{c}{ T4 } & \multicolumn{1}{c}{ T5 } & SE \\
\hline CW & $1610.00^{\mathrm{a}}$ & $1526.67^{\mathrm{ab}}$ & $1540.00^{\mathrm{ab}}$ & $1451.67^{\mathrm{b}}$ & $1560.00^{\mathrm{ab}}$ & 43.91 \\
CCW & 1490.60 & 1446.83 & 1527.17 & 1440.50 & 1547.58 & 40.33 \\
CD \% & 75.46 & 75.42 & 71.99 & 73.57 & 72.48 & 3.59 \\
Liver & 27.00 & 26.08 & 24.83 & 24.50 & 29.58 & 1.90 \\
Lung & 13.50 & 14.83 & 14.83 & 13.67 & 14.50 & 3.30 \\
Gizzard & $26.67^{\mathrm{b}}$ & $38.00^{\mathrm{a}}$ & $35.83^{\mathrm{a}}$ & $36.33^{\mathrm{a}}$ & $35.17^{\mathrm{a}}$ & 2.47 \\
Heart & 9.17 & 10.50 & 10.33 & 15.00 & 17.33 & 4.73 \\
Spleen & $1.96^{\mathrm{ab}}$ & $2.17^{\mathrm{a}}$ & $1.92^{\mathrm{ab}}$ & $1.67^{\mathrm{b}}$ & $2.33^{\mathrm{a}}$ & 0.16 \\
GES & 1.50 & 1.33 & 1.17 & 1.17 & 1.17 & 0.23 \\
& & & & & & \\
\hline
\end{tabular}

${ }^{a, b}$ Within a row, means with common superscript were not different with probability $P<0.05$

T1: positive control with $300 \mathrm{~g} / \mathrm{ton}$ Zinc bacitracin and $500 \mathrm{~g} / \mathrm{ton}$ Salinomycin, T2: $1000 \mathrm{~g} / \mathrm{ton}$ Moringa oleifera leaf meal (MOLM), T3: $500 \mathrm{~g} /$ ton probiotic, T4: $1000 \mathrm{~g} / \mathrm{ton}$ organic acid, T5: negative control, without additives, CW: carcass weight, CCW: chilled carcass weight, CD \%: dressing percentage, GES: gizzard erosion score

Physico-chemical traits such as $\mathrm{pH}$-value, colour and cumulative drip loss are important in determining meat quality (Janisch et al., 2012). Fletcher (2002) reported that threshold pH values below 5.7 stand for pale, soft and exudative (PSE), values 5.7 to 6.1 for standard quality, and values above 6.1 for dark, firm and dry (DFD) meat. The current study did not show any variability in the $\mathrm{pH}$ values of meat across the treatments. These results are consistent with Łukasiewicz et al. (2014), who reported no significant differences caused by plant additives on the ultimate $\mathrm{pH}$ (5.70 - 5.76) of broiler meat. Nkukwana et al. (2015) reported no significant effects $(P>0.05)$ on breast meat $\mathrm{pH}$ measurements of broiler fed MOLM at $1 \%, 3 \%$ and $5 \%$ of DM intake. In their study, pH values ranged from 5.74 to 5.90 . Although no treatment effects were shown on $\mathrm{pH}$ attributes in the current study, the $\mathrm{pH}$ levels ranged between 5.8 and 6.0 at 45 min and 24 hours $\left(\mathrm{pH}_{24}\right)$ post mortem. Therefore, PSE and DFD meat conditions were not observed in the current study.

Chicken breast meat generally appears to have a pink colour, which is a desirable characteristic for the consumer (Choo et al., 2014). The muscle pH is related primarily to the biochemical state of the muscle at the time of slaughter following the development of rigor mortis, decreasing from 7.0 to a pHu of approximately 5.4 to 5.7 (Al-Owaimer et al., 2014). The results of this study showed differences $(P<0.05)$ only on $\mathrm{a}^{*}, \mathrm{C}^{*}$ and $\mathrm{H}^{*}$ meat colour values. The birds in T2 had a higher $\mathrm{a}^{*}$ value than those in T3 and T5. The $\mathrm{C}^{*}$ value was higher in T2 birds and lowest in T3 birds. Consequently, the $\mathrm{H}^{*}$ values were significantly lower in T2 birds and the highest value was shown in T3 birds. The higher redness values in meat from birds that were fed MOLM could be attributed to the high levels of dietary iron in Moringa leaves. Iron content is indicated by its concentration of muscle pigment and is contained in the oxymyoglobin, which results in the red colour in meat (Kadim et al., 2003). Gopalakrishnan et al. (2016) reported that Moringa leaf powder contained $28 \mathrm{mg}$ of iron, whereas beef meat has only $2 \mathrm{mg}$. Additionally, the higher $(P<0.001) \mathrm{a}^{*}$ values in T2 birds compared with the negative control showed that colour was stabilized by antioxidants from MOLM. 
Table 5 shows the least square means of physico-chemical meat quality attributes of broilers fed MOLM, probiotic and organic acid feed additives. The ability of muscle to retain moisture is important to meat quality parameters such as colour, which is held in high regard by the industry and consumers (HuffLonergan \& Lonergan, 2005). The current study showed that the birds in T3 had lower $(P<0.05)$ drip loss \% (1.52), and the highest value (2.31) was observed in T2 birds. Consequently, higher $(P<0.05)$ WHC was shown in $\mathrm{T} 3$ birds, but $\mathrm{T} 1$ birds had the lowest. The current findings are difficult to explain, since no differences were observed in meat $\mathrm{pH}_{24}(P>0.05)$ among groups, indicating that $\mathrm{pH}$ may not have been the major factor in drip loss differences. There were no differences between birds that were fed MOLM (T2) and the birds in the other groups. T2 had comparable WHC to the birds in other groups. Zhou et al. (2010) reported a reduced $(P<0.05)$ percentage of drip loss in birds fed probiotic. Poor WHC results in high drip and purge loss from meat and meat products, which can represent a significant loss of weight from carcasses and may affect the yield and quality of processed meats (Aaslyng, 2002). A rapid pH decline post mortem may lead to protein denaturation, with serious consequences for colour, tenderness, and WHC, generating PSE (Hughes et al., 2014). Łukasiewicz et al. (2014) reported that a decrease in pH value is accompanied by reduced water-binding capacity, and an increase in $\mathrm{pH}$ by increased WHC of muscle proteins.

Table 5 Least square means $( \pm S E)$ of physico-chemical meat quality attributes of broiler chickens $(n=60)$ fed diets with Moringa oleifera leaf meal, probiotic or organic acid as feed additives

\begin{tabular}{lrrrrrr}
\hline \multirow{2}{*}{$\begin{array}{c}\text { Meat } \\
\text { attributes }\end{array}$} & quality & \multicolumn{7}{c}{ Dietary treatments } \\
\cline { 2 - 7 } & \multicolumn{1}{c}{ T1 } & \multicolumn{2}{c}{ T2 } & T4 & T5 & SE \\
\hline $\mathrm{pH}_{45}$ & 6.01 & 5.88 & 6.09 & 5.96 & 5.96 & 0.085 \\
$\mathrm{pH}_{24}$ & 5.86 & 5.93 & 5.88 & 5.91 & 5.99 & 0.051 \\
$\mathrm{~L}^{*}$ & 47.89 & 48.87 & 48.29 & 48.47 & 48.80 & 0.599 \\
$\mathrm{a}^{*}$ & $0.97^{\mathrm{ab}}$ & $1.43^{\mathrm{a}}$ & $0.73^{\mathrm{b}}$ & $1.19^{\mathrm{ab}}$ & $0.80^{\mathrm{b}}$ & 0.203 \\
$\mathrm{~b}^{*}$ & 6.77 & 7.52 & 6.39 & 6.63 & 6.57 & 0.405 \\
$\mathrm{C}^{*}$ & $6.89^{\mathrm{ab}}$ & $7.69^{\mathrm{a}}$ & $6.51^{\mathrm{b}}$ & $6.79^{\mathrm{ab}}$ & $6.65^{\mathrm{ab}}$ & 0.410 \\
$\mathrm{H}^{*}$ & $82.53^{\mathrm{ab}}$ & $79.61^{\mathrm{b}}$ & $84.76^{\mathrm{a}}$ & $79.89^{\mathrm{ab}}$ & $83.05^{\mathrm{ab}}$ & 1.828 \\
Drip loss \% & $1.98^{\mathrm{ab}}$ & $2.31^{\mathrm{a}}$ & $1.52^{\mathrm{b}}$ & $2.06^{\mathrm{ab}}$ & $1.54^{\mathrm{b}}$ & 0.225 \\
WHC & $0.36^{\mathrm{c}}$ & $0.38^{\mathrm{abc}}$ & $0.41^{\mathrm{a}}$ & $0.40^{\mathrm{ab}}$ & $0.37^{\mathrm{bc}}$ & 0.011
\end{tabular}

a,b Within a row, means with common superscript were not different with probability $P<0.05$

T1: positive control with $300 \mathrm{~g} / \mathrm{ton}$ zinc bacitracin and $500 \mathrm{~g} / \mathrm{ton}$ salinomycin, T2: $1000 \mathrm{~g} / \mathrm{ton}$ Moringa oleifera leaf meal (MOLM), T3: $500 \mathrm{~g} /$ ton probiotic, T4: $1000 \mathrm{~g} /$ ton organic acid, T5: negative control, without additives, $\mathrm{pH}_{45}: \mathrm{pH}$ at 45 hours post mortem, $\mathrm{pH}_{24}$ : ultimate $\mathrm{pH}, \mathrm{L}^{*}$ : lightness, $\mathrm{a}^{*}$ : redness, $\mathrm{b}^{*}$ : yellowness, $\mathrm{C}^{*}$ : chroma, $\mathrm{H}^{*}$ : hue angle, WHC: waterholding capacity

\section{Conclusions}

Moringa oleifera leaf meal could be fed to broiler chickens with few alterations to their performance or to the size of their digestive organs relative to birds fed AGP, organic acid, and probiotics. Among these additives, MOLM increased meat redness significantly, although the various additives did not affect meat $\mathrm{pH}$.

\section{Acknowledgements}

The authors are grateful to the Professional Development Programme of the Agricultural Research Council and National Research Foundation (NRF) of South Africa Thuthuka Research Grant for funding this work.

\section{Authors' Contributions}

XPN conducted the study, interpreted the research findings statistically and prepared the manuscript. SPN assisted in data collection and manuscript preparation. TTN designed and supervised the study.

\section{Conflict of Interest Declaration}

The authors declare that there are no conflicts of interest. 


\section{References}

Aaslyng, M.D., 2002. Quality indicators for raw meat. In: J.P. Kerry, J.F. Kerry, D. Ledward (eds.). Meat processing. Woodhead, Cambridge, UK. Pp. 157-174.

Abudabos, A.M., Alyemni, A.H., Dafalla, Y.M. \& Khan, R.U., 2016. The effect of phytogenic feed additives to substitute in-feed antibiotics on growth traits and blood biochemical parameters in broiler chicks challenged with Salmonella typhimurium. Environmental Sci. Pollution Res. 23, 24151-24157. DOI: 10.1007/s11356-016-7665-2

Abudabos, A.M., Alyemni, A.H., Dafalla, Y. M. \& Khan R.U., 2017. Effect of organic acid blend and bacillus subtilis alone or in combination on growth traits, blood biochemical and antioxidant status in broilers exposed to salmonella typhimurium challenge during the starter phase. J. Applied Anim. Res. 45(1),538-542. DOI: 10.1080/09712119.2016.1219665

Agboola, A.F., Omidiwura, B.R.O., Odu, O., Popoola, I. O. \& lyayi, E.A., 2015. Effects of organic acid and probiotic on performance and gut morphology in broiler chickens. S. Afr. J. Anim. Sci. 45.

Alidou, C., Salifou, A., Djossou, J., Mazou, M., Tchebo, F.P. \& Soumanou, M.M., 2016. Roasting effect on antiOnutritional factors of the Moringa oleifera leaves. Int. J. Adv. Res. 4, 78-85.

Al Khateeb, W., Bahar, E., Lahham, J., Schroeder, D. and Hussein, E., 2013. Regeneration and assessment of genetic fidelity of the endangered tree Moringa peregrine (Forssk.) Fiori using inter simple sequence repeat (ISSR). Physiol. Mol. Biol. Pla. 19, 157-164.

Al-Owaimer, A.N., Alyemni, A.H., Suliman, G.M. \& Abudabos, A.M., 2014. Effect of different probiotics on breast quality characteristics of broilers under salmonella enterica subsp. typhimurium challenge. Ital. J. Anim. Sci. 13(3), 450454.

Anwar, F., Latif, S., Ashraf, M. \& Gilani. A.H., 2007. Moringa oleifera: A food plant with multiple medicinal uses. Phytother. Res. 21(1), 17-25.

AOAC, 2000. Official methods of analysis, 17th ed. Association of Official Analytical Chemists, Arlington, VA, USA.

Ashayerizadeh, A., Dabiri, N., Ashayerizadeh, O., Mirzadeh, K.H., Roshanfekr, H. \& Mamooee, M., 2009. Effect of dietary antibiotic, probiotic and prebiotic as growth promoters, on growth performance, carcass characteristics and hematological indices of broiler chickens. Pak. J. Biol. Sci. 12, 52-57.

Baurhoo, B., Phillip, L. \& Ruiz-Feria, C.A., 2007. Effects of purified lignin and mannan oligosaccharides on intestinal integrity and microbial populations in the ceca and litter of broiler chickens. Poult. Sci. 86,1070-1078.

Choo, Y.K., Kwon, H.J., Oh, S.T., Um, J.S., Kim, B.G., Kang, C.W., Lee, S.K. \& An, B.K., 2014. Comparison of growth performance, carcass characteristics and meat quality of Korean local chickens and silky fowl. Asian-Australas. J. Anim. Sci. 27, 398-405.

CIE-Lab, 1978. International Commission on Illumination. Recommendations on uniform colour paces, colour difference equations, psychometric colour terms. Supplement No. 2 to CIE publication No. 15 (E-1.3.1) 1971/ (TC-1.3) 1978. Bureau Central de la CIE, Paris, France.

Corduk, M., Ceylan, N., Nese, D. \& Tel., O.Y., 2008. Effects of novel feed additives on performance, carcass traits and E. coli, aerobic bacteria and yeast counts in broilers. Arch. Geflügelk. 72, 61-67.

Eleroğlu, H., Yildirim, A., Nursel, D.I., Şekeroğlu, A. \& Duman, M., 2013. Comparison of meat quality and fatty acid profile in slow-growing chicken genotypes fed diets supplemented with Origanum vulgare or Melissa officinalis leaves under the organic system. Ital. J. Anim. Sci. 12, 395-403.

Fascina, V.B., Pasquali, G.A.M., Carvalho, F.B., Muro, E.M., Vercese, F., Aoyagi, M.M., Pezzato, A.C., Gonzales, E. \& Sartori, J.R., 2017. Effects of phytogenic additives and organic acids, alone or in combination, on the performance, intestinal quality and immune responses of broiler chickens. Braz. J. Poultry Sci. 19, 497-508.

Fletcher, D.L., 2002. Poultry meat quality. Worlds Poult. Sci. J. 58, 131-145.

Gonzalez, R.M. \& Angeles, H.J.C., 2017. Antibiotic and synthetic growth promoters in animal diets: Review of impact and analytical methods. Food Control. 72, 255-267.

Gopalakrishnan, L., Doriya, K. \& Kumar, D.S., 2016. Moringa oleifera: A review on nutritive importance and its medicinal application. Food. Sci. Human. Wellness. 5, 49-56.

Grau, R. \& G. Hamm, G., 1953. Eine enfache Methode zur Bestimmung der Wasserbindung im Muskel. Die Naturwissenschaften 40, 29-30.

Gunal, M., Yayli, G., Kaya, O., karahan, N. \& Sulak, O., 2006. The effects of antibiotic growth promoter, probiotic or organic acid supplementation on performance, intestinal microflora and tissue of broilers. Int. J. Poult. Sci. 5, 149155.

Huff-Lonergan, E. \& Lonergan, S.M., 2005. Mechanisms of water-holding capacity of meat: the role of post-mortem biochemical and structural changes. Meat Sci. 71, 194-204.

Hughes, J.M., Oiseth, S.K., Purslow, P.P. \& Warner, R.D., 2014. A structural approach to understanding the interactions between colour, water-holding capacity and tenderness. Meat Sci. 98, 520-532.

Huyghebaert, G., Ducatelle, R. \& Van Immerseel, F., 2011. An update on alternatives to antimicrobial growth promoters for broilers. Vet. J. 187, 182-88.

Irie, M., Izumo, A. \& Mohri, S., 1996. Rapid method for determining water-holding capacity in meat using video image analysis and simple formulae. Meat Sci. 42, 95-102.

Janisch, S., Wicke, M. \& Krischek, C., 2012. Mitochondrial respiratory and antioxidative enzyme activities in turkey meat. Animal 6, 346-352.

Juniar, I., Widodo, E. \& Sjofjan, O., 2004. Effect of Moringa oleifera leaf meal in feed on broiler production performance. Jurnal IImuilmu Peternakan Brawijaya. 18, 238-242. 
Kadim, I.T., Mahgoub, O., Al-Ajmi, D.S., Al-Maqbaly, R.S., Al-Saqri, N.M. \& Ritchie, A., 2003. An evaluation of Lippens, M., Room, G., DeGroote, G. \& Decuypere, E. 2000. Early and temporary quantitative food restriction of broiler chickens. Effects on performance characteristics, mortality and meat quality. Brit. Poult. Sci. 41, 343-354.

Khan, R.U. \& Naz. S. 2013. Applications of probiotics in poultry production. World Poultry Sci. J. 69, 621-632.

Khan, R.U., Chand, N. \& Ali, A., 2016. Effect of organic acids on the performance of Japanese quails. Pak. J. Zool. 48, 1799-1803.

Kidd, M., 2009. Advances in poultry nutrition. R. Bras. Zootec. 38, 201-204.

Kocher, A., Rodgers, N.J. \& Choct, M., 2004. Efficacy of alternatives to AGPS in broilers challenged with clostridium perfringens. Proceedings of Australian Poultry Science Symposium 16, 130-133.

Kokoszyński, D., Bernacki, Z., Saleh, M., Stęczny, K. \& Binkowska, M., 2017. Body conformation and internal organs characteristics of different commercial broiler lines. Braz. J. Poultry Sci. 19, 047-052.

Kwedibana, J., 2008. Effect of Moringa oleifera leaf meal on the growth rate of broilers. RM0875. Botswana College of Agriculture, Botswana.

Łukasiewicz, M., Pietrzak, D., Michalczuk, M., Mroczek, J., Niemiec, J. \& Chmiel, M., 2014. Effect of selected feed additives used in coccidiosis prophylaxis on growth performance and carcass and meat quality of fast-growing Hubbard Flex chickens. Eur. Poultry. Sci. 78, 1612-9199.

Mbikay, M., 2012. Therapeutic potential of Moringa oleifera leaves in chronic hyperglycaemia and dyslipidemia: A review. Front. Pharmacol. 3, 1-12.

Moyo, B., Masika, P.J., Hugo, A. \& Muchenje, V., 2011. Nutritional characterization of moringa (Moringa oleifera Lam.) leaves. Afr. J. Biotechnol. 10, 12925-12933.

Moyo, B., Oyedemi, S., Masika, P.J. \& Muchenje, V., 2012. Polyphenolic content and antioxidant properties of Moringa oleifera leaf extracts and enzymatic activity of liver from goats supplemented with Moringa oleifera leaves or sunflower seed cake. Meat Sci. 91, 441-447.

National Research Council, 1994. Nutrient requirements of poultry. 9th ed. National Academy Press, Washington DC, USA.

Nkukwana, T.T., 2012. The effect of Moringa oleifera leaf meal on growth performance, gut integrity, bone strength, quality and oxidative stability of meat from broiler chickens. PhD dissertation, University of Fort Hare, Alice, South Africa.

Nkukwana, T.T., Muchenje, V., Masika, P.J., Hoffman, L.C., Pieterse, E. \& Dzama, K., 2015. Proximate composition and variation in colour, drip loss and $\mathrm{pH}$ of breast meat from broilers supplemented with Moringa oleifera leaf meal over time. Anim. Prod. Sci. http://dx.doi.org/10.1071/AN14055

Nkukwana, T.T., Muchenje, V., Pieterse, E., Masika, P.J., Mabusela, T.P., Hoffman, L.C. \& Dzama, K., 2014. Effect of Moringa oleifera leaf meal on growth performance, apparent digestibility, digestive organ size and carcass yield in broiler chickens. Livest. Sci. 161, 139-146.

Phillips, I., Casewell, M., Cox, T., De Groot, B., Friis, C., Jones, R., Nightingale, C., Preston, R. \& Waddell, J., 2004. Does the use of antibiotics in food animals pose a risk to human health? A critical review of published data. J. Antimicrobial Chemotherapy 53(1), 28-52. https://doi.org/10.1093/jac/dkg483

Qwele, K., Hugo, A., Oyedemi, S.O., Moyo, B., Masika, P.J. \& Muchenje, V., 2011. Chemical composition, fatty acid content and antioxidant potential of meat from goats supplemented with Moringa (Moringa oleifera) leaves, sunflower cake and grass hay. Meat Sci. 93, 455-462.

Sacranie, A., Svihus, B., Denstadli, V., Moen, B., Iji, P.A. \& Choct, M., 2012. The effect of insoluble fibre and intermittent feeding on gizzard development, gut motility, and performance of broiler chickens. Poult. Sci. 91, 693-700.

Sanchez, R.N., Sporndly, E. \& Ledin, I., 2006. Effect of feeding different levels of foliage of Moringa oleifera to creole dairy cows on intake, digestibility, milk production and composition. Livest. Sci. 101, 24-31.

SANS, 2008. South African National Standard: The Care and Use of Animals for Scientific Purposes. 1st ed. SANS 10386:2008. South African Bureau of Standards, Standards Division, Pretoria, South Africa. 232 pp.

Wapi, C., Nkukwana, T.T., Hoffman, L.C., Dzama, K., Pieterse, E., Mabusela, T. \& Muchenje, V., 2013. Physicochemical shelf-life indicators of meat from broilers given Moringa oleifera leaf meal. S. Afri. J. Anim. Sci. 3, 43-47.

Zanu, H.K., Asiedu, P., Tampuori, M., Abada, M. \& Asante, I., 2011. Possibilities of using moringa (Moringa oleifera) leaf meal as a partial substitution for fishmeal in broiler chicken diets. Online J. Anim. Feed Res. 2, 70-75.

Zhou, X., Wang, Y., Gu, Q. \& Li, W., 2012. Effect of dietary probiotic Bacillus coagulans on growth performance, chemical composition, and meat quality of Guangxi Yellow chicken. Poult. Sci. 89, 588-593. 